Maria LEWANDOWSKA

DOI : $10.14746 / \mathrm{pp} .2019 .24 .3 .5$

ORCID ID: https://orcid.org/0000-0002-0448-7181

Beata STACHOWIAK

ORCID ID: https://orcid.org/0000-0003-1805-3306

Nicolaus Copernicus University in Toruń

\title{
University in the Period of Changing the Information Flow Model
}

\begin{abstract}
The article aims to present the results of the study regarding the view of modern students at the university. Several research problems were formulated as follows: what sources of information and knowledge about the world do contemporary students use; what are the main goals of higher education according to modern students; why are modern students deciding to start a higher education course; who is an academic teacher for a modern student? The research tool was a questionnaire made available to the students electronically. Research has shown that the University is one of the sources of information for $65 \%$ of students participating in the study. Only the Internet has obtained more indications. Futhermore, Respondents regarded the key objectives of higher education as contributing to the intellectual development of students, vocational training and awarding academic degrees and issuing diplomas. The main reasons why the respondents chose to study at a higher school were: the desire to obtain higher education, the desire for intellectual development and the acquisition of specific practical skills. Academic teachers are for students who have answered the open question, above all persons transferring knowledge. $21 \%$ of them gave the answer "master" and all synonyms of this term.
\end{abstract}

Key words: University, sources of information, academic teacher, higher education

\section{University etos and tasks of higher education facilities in information society}

$T^{1}$ he University was appointed to perform a mission related to the basic issues concerning society. Robert Wolff, who wanted to determine what ideals should dominate in American higher education, identified four models: "the University as a Sanctuary of Scholarship (drawn from the history of the university); the University as a Training Camp for the Proffesions (reflecting its present character); the University as Social Service Station (prediction of the future of the university); the University as an Assembly Line for the Establishment Man (radical critique of the university, an anti-model)" (Wolff, 1969, p. 3). Presenting these four models already in 1969, the researcher perfectly predicted changes to occur in higher education. With the help of their names, he emphatically pointed out that these are transformations going in the wrong direction.

Kazimierz Denek, when writing about university science and education, lists the fundamental duties of universities. The tasks specified by the researcher can be divided into two groups: didactic and socio-educational (Denek, 2011, pp. 63-64).

The duties of didactic character are as follows:

- "production, learning, transfer and dissemination of knowledge;

- love, search, proclamation and defense of the truth;

- accurate reading of the challenges of the knowledge society and meeting them; 
- conducting a dialogue by the participants of the educational process taking place in it;

- conducting scientific research at the highest possible level, socially important, cognitively important and utilitarian" (Denek, 2011a, pp. 63-64).

The university's socio-educational duties include:

- "maintaining the historical and cultural continuity of the nation;

- creating patterns of human behavior and civic attitudes;

- bringing up people who are bright, wise and devoted to Poland;

- care for the university tradition;

- supporting people's chances for raising their level of existence;

- enabling access to knowledge and acquiring competences for all entitled and having appropriate predispositions" (Denek, 2011a, pp. 63-64).

However, the university ethos should be understood, as Denek himself writes, as a set of norms that guide the life of the university community (Denek, 2011a, p. 11). The essence of a normative approach is to seek the answer to the question how it should be, not how it is in reality. Realities often differ from the adopted rules, especially in the information society.

Skepticism about the importance of the university for the production and dissemination of knowledge is understandable. We must not forget that today we are talking about a "knowledge society," that is, an idea that knowledge gives energy that guarantees success (as a key source of economics). All existing organizations, sooner or later, will have to transform into "knowledge" organizations. Universities are not an exception in this matter (Denek, 2011b, p. 75). What's more, there is also (introduced by representatives of UNESCO) a vision of a "proactive university," which underlines the importance of higher education institutions in transferring knowledge. Universities are to be, inter alia: a place where high-quality training is provided, preparing students for civic and professional functions; a place that shapes society fully devoted to exploration, creation, dissemination of knowledge and scientific progress; a place where you promote and improve the quality of knowledge (Denek, 2011b, p. 79).

Supporting people's chances to raise the level of their existence as one of the tasks performed by the university is today exclusively utopia. The situation of university graduates in the modern labor market is aptly described by Zygmunt Bauman: "For the first time since time immemorial, entire classes of graduates face the almost certain proability of occasional, temporary, uncertain part-time employment or unpaid pseudo-employment falsely called 'internship' or 'apprenticeship' - work far below their qualifications and light years below the level of their expectations" (Bauman, 2017, p. 26).

While conducting the socially and cognitively important research at the highest level can still be considered a duty of the university (or rather people employed in it), it is hard to assume that utilitarianism is an immanent feature of the conducted research. Article 4 of the Act of $20^{\text {th }}$ of July 2018 the Law on Higher Education and Science defines basic research as empirical or theoretical works aiming, above all, on acquiring new knowledge about the fundamentals of phenomena and observable facts, without focusing on direct commercial use (Journal of Laws, 2018, item 1668).

Often in academic didactics, the emphasis is placed on the necessity for the students to acquire specific practical skills. According to Izabella Bukraba-Rylska: "[...] as if the 
mission of academic education was to provide labor to the labor market. Neither a right nor an ambitious idea [...]. There is no demand for open minded innovators in a service base functioning in such way, but only for a cheap labor force taught to specific tasks. [...]" (Bukraba-Rylska, 2015, p. 67).

Education programs too often are designed to meet market expectations. As a consequence, it leads to commodification of qualifications of university graduates. At that time, the level of research being conducted, or the broadening of horizons and individual development are not taken care of. Students have to acquire a specific, closed set of professional competences. This is particularly interesting in the context of the previously mentioned problem related to the lack of jobs - although graduates fulfill the tasks set before them, they cannot find employment at the end of education.

\title{
Academic teacher 2.0 versus student of the $21^{\text {st }}$ century - crisis of the master-student relation?
}

In the discourse on university education, the link between an academic teacher and a student has always been given a significant role by defining it as a master-student relationship. One can have doubts whether the creation of such a relationship is still real in the digital society.

Trying to answer the above question, it is worth referring to the arguments presented by Maria Flis and Rafał Drozdowski:

\begin{abstract}
"The fewer direct contacts between students and lecturers, the smaller the chance for authentic master-student relations. The problem is that direct contact [...] is less and less common (nowadays, most exams are written exams, and among them more and more exams take the form of tests). The development of the master-student relationship is also not conducive to the progressive formalization and procedurealization of the university's functioning (of which USOS became the symbol)" (Idea Uniwersytetu..., 2014, p. 121).
\end{abstract}

At present, the view prevails that the building of a deeper relationship between two or more persons is possible at a distance via electronic devices and universal access to the Internet. Although this is quite a controversial statement, you can agree with it, but only in relation to the ties between students who are representatives of the fifth generation - Z generation (also called Generation C), established by those born after 1995, but not later than in the middle of the first decade of the $21^{\text {st }}$ century (Sajduk, 2014, p. 14). On the other hand, academic teachers are representatives of the second, third and, increasingly, fourth generation - the so-called Baby Boomers (people who came into the world after the end of World War II, the final caesura for this generation are the early 1960s); Generation X (people born in 1965-1981); Generation Y/Millennium Generation (between 1982 and 1995) (Sajduk, 2014, pp. 13-14).

The inability to build a deeper quasi-master-student relationship in an indirect way is dictated by the fact that modern students form a group of digital natives, while academic teachers are mostly digital immigrants (Prensky, 2001). Prensky suggests that today's students think and process information in a different way than their predecessors. Computer games, mobile phones and instant messages are an integral part of life, 
which makes them native users of digital language and modern technologies. Digital immigrants, though they can find a good place in the virtual world, will never be able to match digital natives. Referring to the issue of formalization and proceduralisation of the university's operation, it should be agreed with Flis and Drozdowski that the University System of Studies' Service (USOS) became the symbol of these processes. Perfectly known to all students and academic teachers, it undoubtedly contributed to reducing the bond between the master and the student. All you have to do is give examples of how to use the system. The paper indexes have been replaced by the appropriate "tab" in the profile of each student, thus a visit to the lecturer aimed at entering the final grade of the subject is no longer a necessity. Another exemplification - about one hundred people study at the first year of undergraduate studies. The same subject is run by two teachers. Even if all students would like to sign up for the same lecturer - this is not possible due to the limit of places. Some of them will be compulsorily sent to the group which they did not want to join. This, in turn, may translate into a reluctance to build a master-student relationship with a lecturer. In addition, with such a large group of students, dedicating enough time and attention to each student ceases to be possible.

Anna Sajdak concludes that there is still the possibility of a master-student relationship, but only during meetings in a small group: "The last such bastions of work in small groups are usually master's and doctoral seminars [...]. Being a supervisor of a thesis or doctoral thesis means the involvement of an academic teacher in guiding the student's academic development or actively assisting in the development and support of it. The promoter should therefore be just a master previously described, who reveals the secrets of his own research workshop, supports the student or doctoral student in his research and scientific writing" (Sajdak, 2013, pp. 147-148).

\section{Research methodology}

A questionnaire was conducted in which students were the respondents. The research tool was a questionnaire made available to the reviewers electronically. It contained six closed questions and one open question. Percentages on charts that illustrate research results do not add up to $100 \%$, because in closed questions respondents could choose more than one answer.

Three closed questions were aimed at gathering information about the respondents who found themselves in a research sample of 250 people. $61 \%$ of respondents were women, and $39 \%$ were men. Most of the respondents are students of the $1^{\text {st }}(26 \%), 2^{\text {nd }}(21 \%)$ or $3^{\text {rd }}$ (21\%) year of undergraduate/uniform MA studies. Students of the $1^{\text {st }}$ year of MA studies, $4^{\text {th }}$ year of uniform MA studies, $5^{\text {th }}$ year of uniform MA studies and doctoral students were respectively $17 \%, 13 \%$ and $2 \%$ of respondents. The vast majority study humanities $(85 \%)$, $(12 \%)$ exact sciences, $(2 \%)$ artistic and $(1 \%)$ interdisciplinary majors.

Answer to the open question "Who is an academic teacher to you?" were given by 150 people.

Several research problems were formulated as follows:

- What sources of information and knowledge about the world do contemporary students use? 
- What are the main goals of higher education according to modern students?

- Why are modern students deciding to start a higher education course?

- Who is an academic teacher for a modern student?

The above-mentioned questions are answered by research hypotheses:

- modern students, in order to acquire knowledge about the world, use the Internet in the first place, the university has ceased to be one of the sources of information for them;

- according to modern students, the most important goal of higher education today is to give titles and degrees and to enable them to obtain diplomas;

- modern students usually start their studies in a higher education institution in order to obtain a higher education and a title/diploma;

- for a modern student, an academic teacher is the only lecturer at the university. Currently, he is not a master/mentor for the students.

\section{Analysis of test results and verification of hypotheses}

The first problem that was taken up in the study was to define the sources of information most often used by students. Chart 1 illustrates how many respondents indicated particular sources.

Chart 1. Information sources of modern students

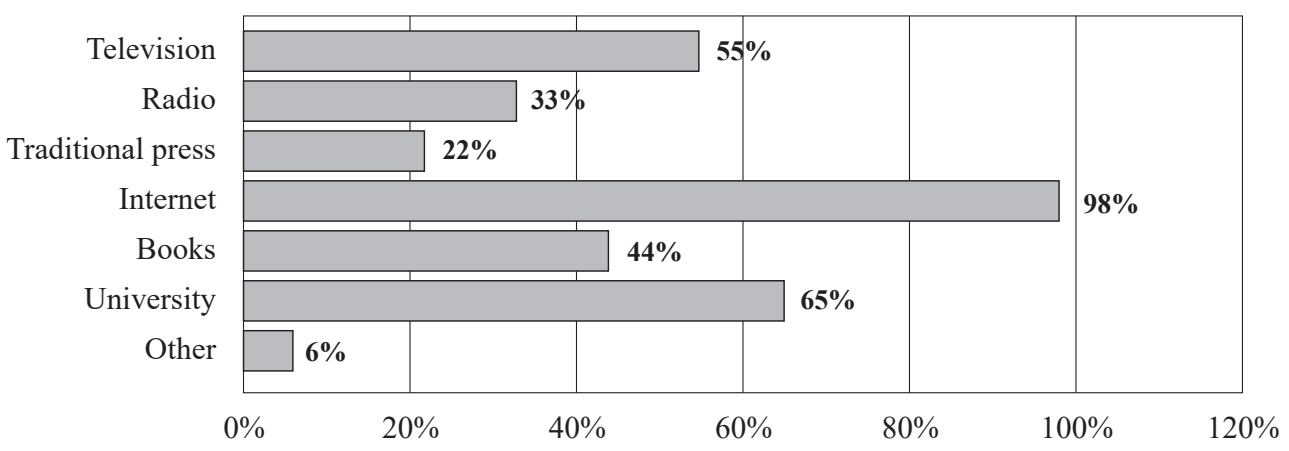

Source: Own elaboration.

The Internet is the most frequently indicated source of information by respondents ( $98 \%$ of respondents chose that answer). What is the most important in the context of this study, the university was at the second place in terms of the number of indications (65\%). Television (55\%) and books (44\%) ranked third and fourth. Thus, it can be concluded that the hypothesis regarding the types of information sources that modern students use, should be considered only partially positive. While the Internet turned out to be the undisputed leader among the sources of knowledge, it cannot be unequivocally stated that the university lost such a function according to the respondents. Of course, due to the widespread access to the Internet and its popularity among students, the university cannot compare to it as a source of knowledge and information. Another issue is the honesty 
of people in the study. It is likely that students have recognized the university as the answer that is expected of them. They were informed about the total anonymity of the study, but perhaps they wanted to present themselves from the best side.

\section{Chart 2. Key objectives of higher education according to students}

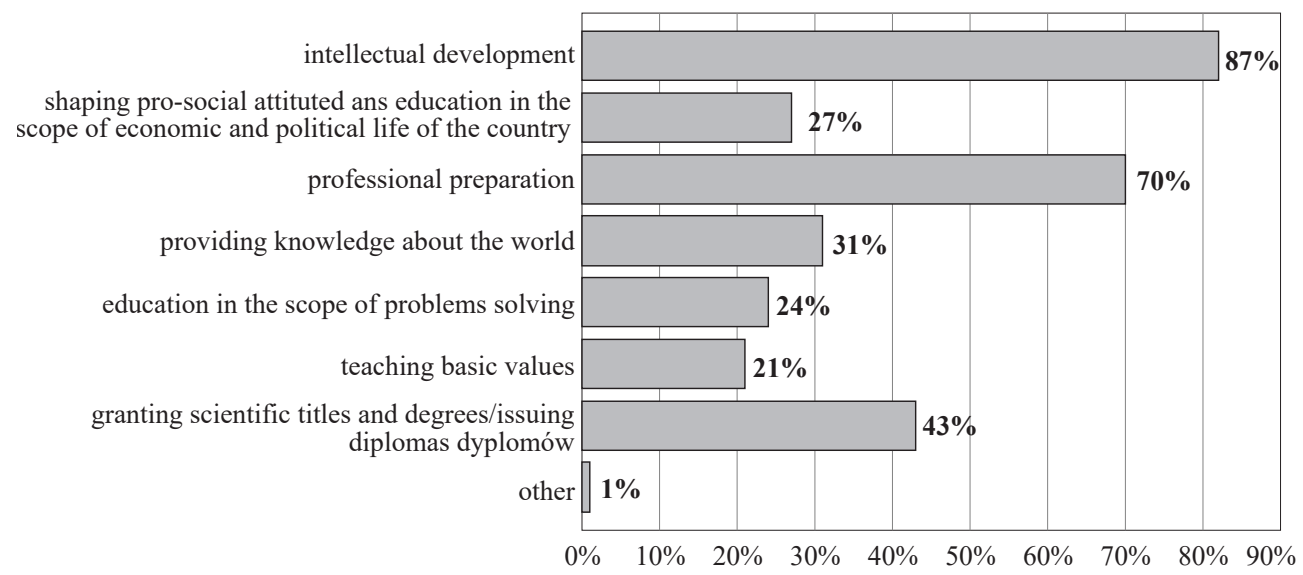

Source: Own elaboration.

Another research problem was about what higher education goals students consider the most important (chart 2). Three responses were indicated more often than others. As a key goal, students recognized intellectual development ( $82 \%$ of respondents gave such an answer). The majority of respondents (70\%) considered that the university should provide students with adequate preparation for starting work in their dream job (and thus guarantee the acquisition of specific practical skills). The hypothesis regarding the key objectives that the university should pursue as an institution has therefore been verified negatively to a significant degree. Giving academic degrees and issuing diplomas was not only not the most popular answer given by the respondents, but was only indicated by just over $40 \%$.

Another issue had a more personalized character. Respondents had to answer why they chose to start studying at a university. The frequency of giving individual answers was illustrated by means of chart 3 .

The hypothesis assumed in this case that the most popular answer would be the one referring to obtaining a degree and obtaining a higher education and obtaining a diploma. Based on the obtained results, it can be assumed that it has been positively verified, though not to a full extent. It is impossible not to pay attention to two issues. First of all, this answer was not indicated much more frequently than answers regarding intellectual development (66\%), acquisition of specific skills (59\%) or broadening of horizons (55\%). It should therefore be recognized that the desire to acquire higher education is usually accompanied by other premises that make students start university education.

Moreover, it is worth emphasizing that respondents' answers, considering the second and third questions, seem to be partly inconsistent. In both of the aforementioned 


\section{Chart 3. Reasons for studying at a university}

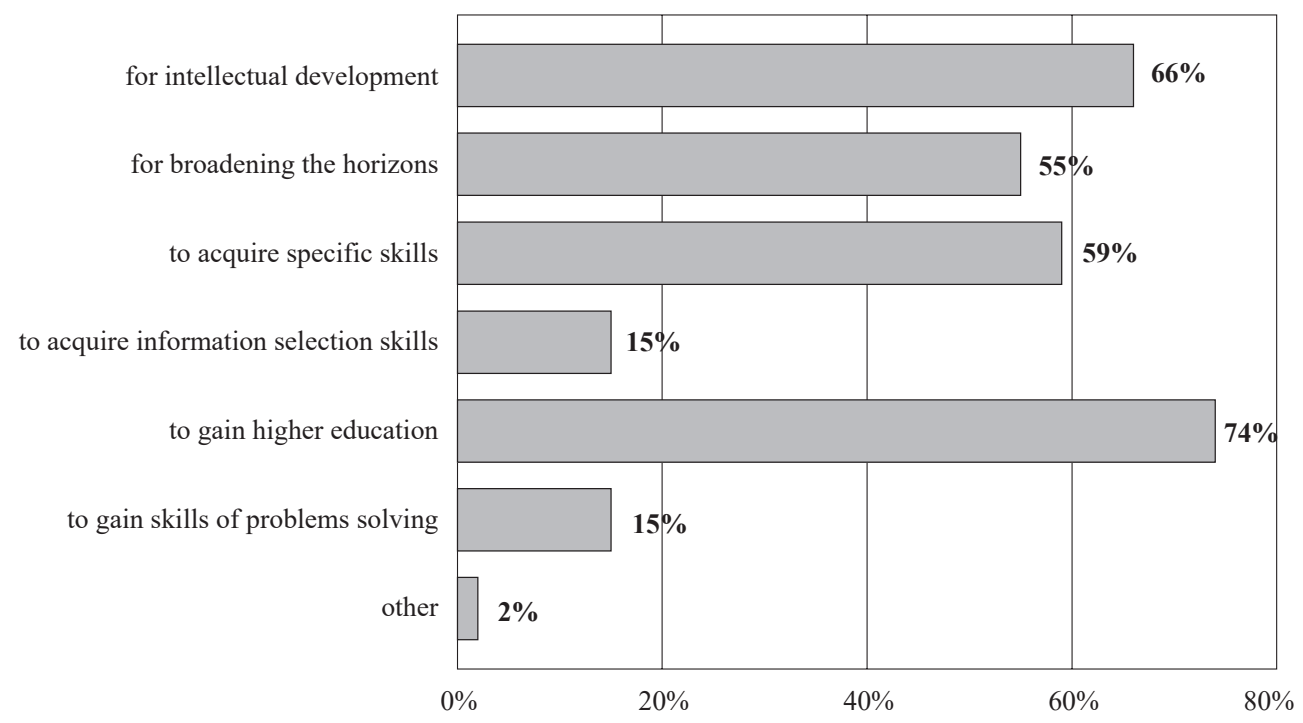

Source: Own elaboration.

questions, the respondents had a choice of similar answers. In the question about the most important, in their opinion, goals to be achieved by the university, the respondents most often indicated that they contributed to the intellectual development of students (82\%). Only $43 \%$ of respondents indicated the awarding of academic degrees and the issuing of diplomas, whereas in the question about the reasons for starting university education a similar answer was chosen most often and obtained a result of $74 \%$. It is clear that as long as the question concerned the duties of the University, and thus was to be a kind of characteristic of its ideal type, the respondents pointed to the objectives related to self-development of students. When they were to indicate the reason why they started their studies themselves, they admitted that their main goal is to acquire higher education. In practice, this means that students somehow contribute to the discrepancy between what mission the university should accomplish and what activities are actually undertaken by its managers. For them, the highest number of candidates for studies is a priority. The university cannot exist without students. If a particular University does not meet the expectations of the student and does not provide what is expected, the candidate will decide to start learning in another facility.

The respondents were asked to answer one open question regarding their attitude towards academic teachers. After analyzing the answers, it was possible to group them thanks to repeated determinations.

Figure 4 distinguishes one of the answers. The majority (45\%) of respondents declared that in their opinion an academic teacher is a person providing knowledge and information to their students. The respondents emphasized that they must have appropriate education / competences / qualifications / skills Academic teacher is a person who has extensive knowledge in their field and is willing to pass it on to others. 


\section{Chart 4. Academic teacher according to students}

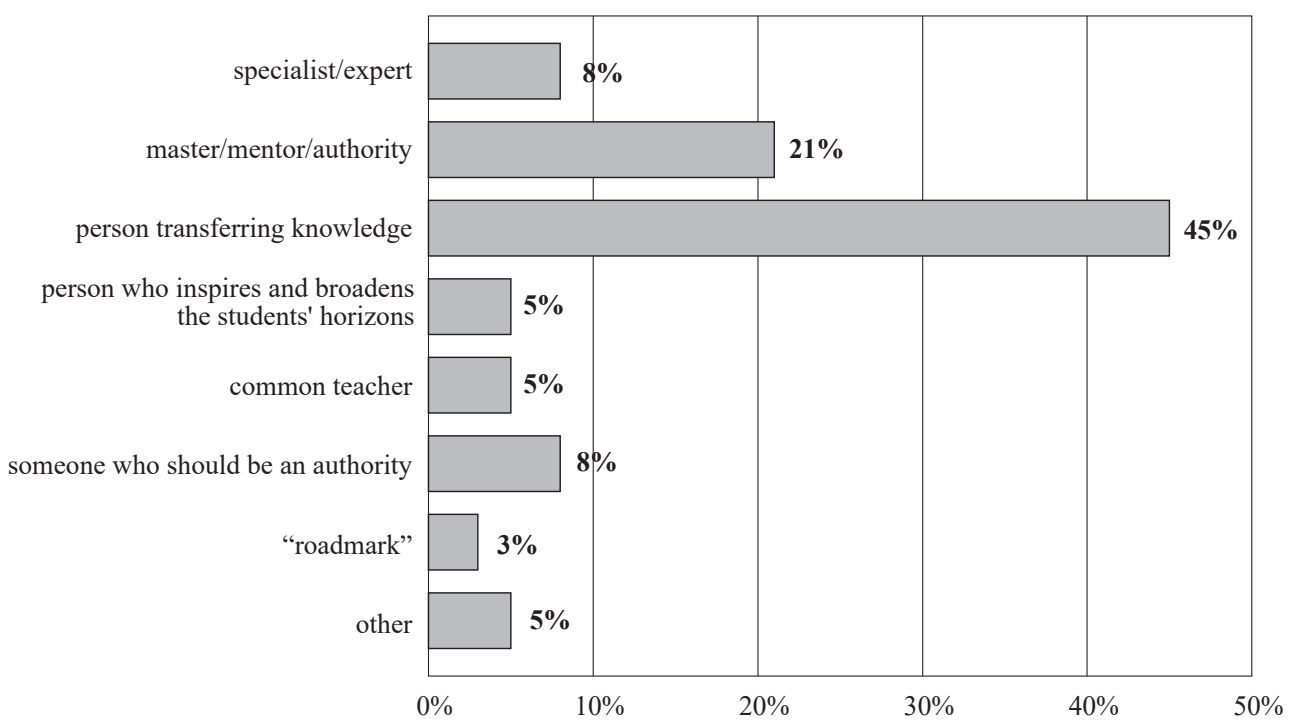

Source: Own elaboration.

The second most frequently repeated term defining an academic teacher (21\%) was the authority and the synonymous words (mentor, model, master), e.g.: The moral and scientific authority or He is an authority and a person with a large knowledge base. Importantly, the second answer in terms of the number of responses, was chosen twice as rarely.

The remaining answers were indicated episodically. It is worth mentioning, however, that some respondents (8\%) made a clear distinction between who an academic teacher should be and who he is, for example:

"Maybe I will write about who he should be, because unfortunately, he not always is (quite often). He should be the authority for the student, which he deserved by his knowledge, the ability to communicate it, his scientific achievements and highlevel personal culture."

or

"[He is] a kind of mentor who should teach and advise, he should do it with passion which unfortunately cannot be experienced, the student is treated as a piece or something extra and basically unimportant."

Analyzing the respondents' answers, it can be concluded that the hypothesis regarding how students perceive academic teachers at present has been verified to a large extent positively. For most of the respondents, the lecturer is above all a person who has to transfer knowledge from a specific field. It should be noted, however, that the second most commonly used term for defining an academic teacher was the word "master" and its synonyms. Only $21 \%$ of the respondents 
used such formulations, but it raises hopes that the master-student relationship is still possible to be obtained.

\section{Conclusions}

1. The University is one of the sources of information for $65 \%$ of students participating in the study. Only the Internet has obtained more indications. It is difficult to say whether these are honest opinions of respondents, or whether they considered that they were expected to give the answer "University."

2. Respondents regarded the key objectives of higher education as contributing to the intellectual development of students (82\%), vocational training (70\%) and awarding academic degrees and issuing diplomas (43\%).

3. The main reasons why the respondents chose to study at a higher school were: the desire to obtain higher education (74\%), the desire for intellectual development $(66 \%)$ and the acquisition of specific practical skills (59\%).

4. Academic teachers are for students who have answered the open question, above all persons transferring knowledge. $21 \%$ of them gave the answer "master" and all synonyms of this term.

\section{Bibliography}

Wolff R. P. (1969), The Ideal of the University, Beacon Press, Boston.

Denek K. (2011a), Uniwersytet w pespektywie społeczeństwa wiedzy. Nauka i edukacja w uniwersytecie XXI wieku, Wyższa Szkoła Pedagogiki i Administracji im. Mieszka I, Poznań.

Denek K. (2011b), Uniwersytet w perspektywie społeczeństwa wiedzy. Dydaktyka akademicka i jej efekty, Wyższa Szkoła Pedagogiki i Administracji im. Mieszka I, Poznań.

Tunnermann C. (1996), A new vision higher education, "Higher Education Policy", no 1 [za:] Denek K. (2011), Uniwersytet w perspektywie społeczeństwa wiedzy. Dydaktyka akademicka i jej efekty, Wyższa Szkoła Pedagogiki i Administracji im. Mieszka I, Poznań.

Bauman Z. (2017), Wyzwania dla edukacji w dobie ptynnej nowoczesności, w: Uniwersytety, naukowcy i studenci w zglobalizowanym świecie, pod. red. R. Siemieńskiej, SCHOLAR, Warszawa.

The Act of 20th of July 2018, the Law on Higher Education and Science (Journal of Laws 2018, item 1668).

Bukraba-Rylska I. (2015), „Lawina” $i$,,kamienie”, czyli pole akademickie w procesie transformacji, w: Szkolnictwo wyższe, uniwersytet, kształcenie akademickie w obliczu koniecznej zmiany, pod. red. M. Szczepańskiego, K. Szafraniec, A. Śliz, PAN, Warszawa.

Idea Uniwersytetu. Reaktywacja (2014), pod. red. P. Sztompki, K. Matuszka, Wydawnictwo Uniwersytetu Jagiellońskiego, Kraków.

Sajduk B. (2014), Pokolenie Y a metody dydaktyki akademickiej, „Kultura i Polityka: Zeszyty Naukowe Wyższej Szkoły Europejskiej im. ks. Józefa Tischnera w Krakowie”, nr 16.

Prensky M. (2001), Digital Natives, Digital Immigrants, On the Horizon, University Press, vol. 9, https:/www.marcprensky.com/writing/Prensky\%20-\%20Digital\%20Natives,\%20Digital\%20 Immigrants\%20-\%20Part1.pdf, 25.03.2019.

Sajdak A. (2013), Paradygmaty kształcenia studentów i wspierania rozwoju nauczycieli akademickich, Impuls, Kraków. 


\section{Uniwersytet w okresie zmiany modelu przeplywu informacji}

\section{Streszczenie}

Artykuł ma na celu zaprezentowanie wyników badan dotyczących poglądów współczesnych studentów na uniwersytet. Sformułowano kilka problemów badawczych: z jakich źródeł informacji i wiedzy o świecie korzystają współcześni studenci; jakie są główne cele szkolnictwa wyższego według współczesnych studentów; dlaczego współcześni studenci decydują się na rozpoczęcie studiów wyższych; kim jest nauczyciel akademicki dla współczesnego studenta? Narzędziem badawczym był kwestionariusz ankiety udostępniony studentom drogą elektroniczną. Badania wykazały, że uniwersytet jest jednym ze źródeł informacji dla $65 \%$ studentów biorących udział w badaniu. Więcej wskazań uzyskał jedynie Internet. Ponadto, respondenci za kluczowe cele szkolnictwa wyższego uznali przyczynianie się do rozwoju intelektualnego studentów, przygotowanie zawodowe oraz przyznawanie stopni naukowych i wydawanie dyplomów. Głównymi powodami, dla których respondenci zdecydowali się podjąć studia w szkole wyższej były: chęć zdobycia wyższego wykształcenia, chęć rozwoju intelektualnego i chęć nabycia określonych umiejętności praktycznych. Nauczyciele akademiccy są dla studentów, przede wszystkim, osobami przekazującymi wiedzę. $21 \%$ spośród ankietowanych udzieliło odpowiedzi „mistrz” (lub użyło synonimu tego słowa).

Słowa kluczowe: uniwersytet, źródła informacji, nauczyciel akademicki, szkolnictwo wyższe 